\title{
PERILAKU INVESTASI ANAK MENENTUKAN PERAN NILAI ANAK DALAM KESEJAHTERAAN ANAK
}

\author{
Zifora Mujahidah Villa ${ }^{1^{*}}$, Euis Sunarti ${ }^{2}$, Istiqlaliyah Muflikhati ${ }^{2}$ \\ ${ }^{1}$ Program Studi IImu Keluarga dan Perkembangan Anak, Sekolah Pascasarjana, \\ IPB University, Bogor 16680, Indonesia \\ ${ }^{2}$ Departemen IImu Keluarga dan Konsumen, Fakultas Ekologi Manusia, \\ IPB University, Bogor 16680, Indonesia
}

")E-mail: zeefora@gmail.com

\begin{abstract}
Abstrak
Kesejahteraan anak baik objektif maupun kesejahteraan subjektif yang tinggi adalah tanggung jawab keluarga. Beberapa faktor yang diduga dapat memengaruhi kesejahteraan anak adalah nilai anak yang dimiliki keluarga dan juga perilaku investasi anak yang dilakukan keluarga. Penelitian ini bertujuan untuk menganalisis pengaruh nilai anak dan perilaku investasi anak terhadap kesejahteraan anak laki-laki dan perempuan yang tinggal di rumah susun. Penelitian ini menggunakan desain cross sectional study melibatkan 119 keluarga (60 ibu beserta anak laki-laki dan 59 ibu beserta anak perempuan) di rumah susun sewa (rusunawa) Jatinegara, Jakarta. Keluarga dipilih secara disproportional stratified random sampling berdasarkan jenis kelamin anak. Analisis data menggunakan independent t-test dan analisis SEM (Structural Equation Modelling). Hasil penelitian menunjukkan bahwa nilai anak dan kesejahteraan anak dalam penelitian ini terkategori sedang, sedangkan perilaku investasi anak terkategori rendah. Selain itu, tidak ditemukan adanya perbedaan nilai anak, perilaku investasi anak, dan kesejahteraan anak antara laki-laki dan perempuan. Hasil analisis uji SEM membuktikan bahwa perilaku investasi anak berpengaruh langsung positif signifikan terhadap kesejahteraan anak. Adapun nilai anak berpengaruh tidak langsung terhadap kesejahteraan anak melalui perilaku investasi anak.
\end{abstract}

Kata kunci: kesejahteraan anak, kesejahteraan objektif, kesejahteraan subjektif, nilai anak, perilaku investasi anak

\section{Parental Investment: Determinate Role of Values of Children on Child Well-being}

\begin{abstract}
The high of both objective and subjective child well-being are family's responsibility. Some factors that are predicted to affect the child well-being are the values of child owned by the family and also the investment behavior of the child (parental investment behavior). This research aims to analyze the influence of values of children and the parental investment behavior to child well-being between boys and girls. This research used a cross sectional study design and involved 119 families (60 mothers with sons and 59 mothers with daughters) in a rental flat (Rusunawa Jatinegara) Jakarta. Samples were chosen using disproportional stratified random sampling based on gender. Independent t-test and SEM (Structural Equation Modeling) was used for the data analysis. The results showed that the values of children and the child well-being were in the medium category. However, parental investment behavior was is in low category. Result of this research does not show any difference in values of children, parental investment behavior, and child well-being between boys and girls. The influence test result used SEM shows that parental investment behavior has a significant postive direct effect on child wellbeing. The value of children has a indirect effect on child well-being through parental investment behavior.
\end{abstract}

Keywords: child well-being, objective well-being, parental investment behavior, subjective well-being, values of children.

\section{PENDAHULUAN}

Masa kanak-kanak merupakan satu tahapan perkembangan manusia yang akan menjadi pondasi kualitas seorang individu. Konvensi Hak Anak (KHA) yang kemudian diratifikasi dalam Undang Undang Perlindungan Anak (UUPA) mengolongkan masa kanak-kanak dalam rentan usia nol tahun hingga delapan belas tahun. Remaja adalah fase terakhir periode anak-anak sebelum memasuki gerbang kedewasaan. Sebagai generasi penerus bangsa, kualitas dan kesejahteraan remaja seharusnya menjadi perhatian utama. Peningkatan kesejahteraan remaja diharapkan mampu menghasilkan generasi-generasi 
berkualitas yang mampu menjadikan Indonesia maju di kemudian hari. Komposisi penduduk remaja yang mencapai 16,5 persen (BPS, 2019) dengan kesejahteraan yang baik akan menjadi sumber daya yang berkualitas sehingga mampu mendorong pembangunan Indonesia. Namun, banyak data yang menunjukan masih kurangnya kesejahteraan anak khususnya pada rentang umur remaja di Indonesia. Kementerian Pendidikan dan Kebudayaan (2017) mencatat bahwa pada Tahun Ajaran 2016/2017 ada 38.700 siswa SMP, 36.149 siswa SMA, dan 72.744 siswa SMK mengalami putus sekolah. Tidak hanya putus sekolah, Kementerian Ketenagakerjaan (2014) juga mencatat 4.025 anak-anak hingga remaja 17 tahun menjadi pekerja di bawah umur. Program-program pemerintah seperti pembebasan biaya sekolah, pelarangan melalui Undang-Undang mempekerjakan anak di bawah umur belum cukup untuk meningkatkan kesejahteraan anak. Keluarga menjadi kunci penting dalam pemenuhan kesejahteraan anak baik kesejahteraan objektif maupun kesejahteraan subjektif anak (KPPPA, 2016; Lampropoulou, 2018). Salah satu yang dapat dilakukan oleh keluarga adalah dengan melakukan investasi pada anak.

Perilaku investasi pada anak mampu menjadi jembatan bagi anak tersebut melanjutkan generasi dan hidup sejahtera (Rahmiati \& Puspitawati, 2013; Vasilyeva, Dearing, Ivanova, Shen, \& Kardanova, 2018). Perilaku investasi anak terbagi menjadi dua, yaitu investasi dalam bentuk materi dan dalam bentuk nonmateri. Investasi materi dapat dilakukan dengan cara memberikan fasilitas pendidikan, asuransi kesehatan untuk anak, hingga memberikan tempat tinggal yang layak (Sohr-Presto et al., 2013). Investasi nonmateri dapat dilakukan orang tua dengan memberikan kelonggaran waktu untuk menemani anak belajar, menemani berdiskusi, hingga melakukan aktivitas olahraga bersama (Sohr-Presto et al., 2013). Perilaku investasi yang baik dapat dilakukan oleh keluarga, salah satunya jika keluarga juga memiliki pandangan terhadap nilai anak yang juga baik.

Kehadiran anak di dalam keluarga selalu dikaitkan dengan biaya, konsumsi, dan waktu untuk merawat anak (Cardia \& Gommen, 2018), padahal sebuah rumah tangga dengan anak juga mampu menjadi unit produksi (Folbre, 2008). Anak yang dibesarkan dengan baik akan mampu membantu serta menjaga orang tua ketika tua, bahkan anak yang tumbuh dengan kualitas baik akan dapat menambah penghasilan pajak negara (Folbre,
2008). Beban membesarkan anak yang dirasakan orang tua akan menyebabkan nilai anak yang dimiliki keluarga menjadi negatif sedangkan kepuasan dan kegunaan yang dirasakan orang tua dengan hadirnya anak dapat menyebabkan nilai anak yang dirasakan orang tua menjadi positif (Hartoyo, Latifah, \& Mulyani, 2011). Orang tua dengan persepsi positif dan harapan tinggi kepada anak akan memiliki perilaku investasi yang tinggi pula untuk anak. Sam (2001) mengungkapkan bahwa dalam mengkaji nilai anak (values of children) dapat terbagi menjadi tiga dimensi, yaitu nilai anak psikologis, sosial, dan ekonomi.

Penelitian di lingkungan rumah susun sewa (rusunawa) sudah pernah dilakukan oleh Januardi, Achmadi, dan Fortuna (2017) terkait penggusuran yang dialami oleh penghuni di dalamnya. Rusunawa Jatinegara adalah salah satu rusun yang menjadi tujuan tempat tinggal warga yang mengalami penggusuran pada tahun 2015. Keluarga korban penggusuran tersebut kini menempati rumah susun dengan sistim sewa dan keluarga diperbolehkan tinggal dengan pembayaran bulanan tanpa kepemilikan. Menurut penelitian Syafruddin dan Adi (2017), keluarga di rusunawa dihadapkan dengan kenaikan pengeluaran. Kenaikan pengeluaran serta ketidakkepemilikan aset rumah menjadi indikasi keluarga tidak memiliki kesejahteraan objektifnya (Jiang, Zhang, Ming, \& Lin 2019).

Permasalahan ekonomi yang dialami oleh keluarga rusunawa menjadi faktor risiko dalam perilaku investasi orang tua terhadap anak. Penelitian Sohr-Preston et al. (2013) dan Hartoyo (1988) menyebutkan bahwa keluarga dengan kesulitan ekonomi lebih sedikit akan mengeluarkan dana untuk berinvestasi pada anak dibandingkan dengan keluarga tanpa kesulitan ekonomi. Rahmawati (2013) dalam penelitiannya membuktikan bahwa orang tua yang berpendapatan rendah memiliki waktu lebih sedikit untuk memperhatikan perkembangan anak. Penelitian lain juga menyebutkan bahwa keluarga dengan tekanan dan terdesak juga kerap kali harus memilih untuk berinvestasi antara anak laki-laki dan perempuan (Chen, 2017; Pufall et al., 2016). Hal tersebut menjadi penduga bahwa kesulitan ekonomi yang dialami keluarga di rusunawa menjadi faktor penghalang mencapai kesejahteraan anak serta menjadi faktor orang tua membedakan antara anak laki-laki dan perempuan yang kemudian ingin dibuktikan dalam penelitian ini. Oleh karena itu, penelitian ini bertujuan untuk mengidentifikasi karakteristik keluarga, karakteristik anak, nilai anak dan 
perilaku investasi anak pada keluarga yang tinggal di Rusunawa Jatinegara; menganalisis perbedaan nilai, perilaku investasi, dan kesejahteraan anak perempuan dan laki-laki; dan menganalisis pengaruh karakteristik keluarga, karakteristik anak nilai anak, dan perilaku investasi anak terhadap kesejahteraan anak remaja warga Rusunawa Jatinegara.

\section{METODE}

Penelitian ini menggunakan desain cross sectional study. Penelitian ini dilakukan di rumah susun sederhana sewa (rusunawa) Jatinegara Barat, Jakarta Timur. Lokasi tersebut dipilih secara purposive. Penelitian ini pada awalnya melibatkan 60 ibu dengan anak laki-lakinya serta 60 ibu dengan anak perempuannya. Namun dikarenakan satu anak perempuan bersaudara dengan satu anak lainnya maka satu remaja perempuan harus dihilangkan saat pengolahan data. Oleh karena itu, penelitian ini melibatkan 60 remaja laki-laki dan 59 remaja perempuan beserta ibunya untuk melihat persepsi nilai anak dan perilaku investasi anak yang dilakukan keluarga. Keluarga contoh dipilih secara stratified disproposional random sampling berdasarkan jenis kelamin anak dengan responden adalah ibu dan anak. Anak dalam penelitian ini adalah individu laki-laki dan perempuan yang berada di rentang usia 13-18 tahun pada saat pengambilan data dilakukan.

Data yang digunakan dalam penelitian ini berupa data primer yang dikumpulkan melalui wawancara. Data primer meliputi karakteristik keluarga, karakteristik anak, nilai anak, perilaku investasi anak dan kesejahteraan anak. Wawancara kepada ibu dilakukan untuk menjawab kuesioner mengenai nilai anak dan perilaku investasi. Sementara itu, wawancara kepada anak dilakukan untuk menjawab kuesioner kesejahteraan anak.

Nilai anak adalah sebuah konstruk psikologis yang mengacu pada manfaat memiliki anak dibandingkan dengan biaya dan kerugian yang dikeluarkan (Sam, 2001). Nilai anak diukur berdasarkan kuesioner nilai anak yang dikembangkan Larasati dan Hartoyo (2016). Instrumen tersebut terdiri dari tiga dimensi yaitu nilai psikologi, sosial, dan ekonomi. Kuesioner nilai anak mencakup 23 butir pernyataan. Responden ibu diminta menjawab setiap butir pernyataan dengan jawaban sebagai berikut: $0=$ tidak setuju, $1=$ kurang setuju, $2=$ setuju, $3=$ sangat setuju. Kuesioner nilai anak memiliki Cronbach's alpha sebesar 0,855.
Perilaku investasi anak adalah segala usaha, aktivitas, dan alokasi sumber daya keluarga yang bertujuan untuk meningkatkan kualitas anak (Hatoyo, 1998). Kuesioner yang digunkan untuk mengukur perilaku investasi anak mengacu pada kuesioner Surachman dan Hartoyo (2015) yang memiliki dua dimensi, yaitu perilaku materi dan nonmateri. Kuesioner perilaku investasi anak menpunyai 17 butir pernyataan yang menggambarkan perilaku investasi anak yang dilakukan keluarga. Responden ibu diminta menjawab setiap butir pernyataan dengan jawaban sebagai berikut: $0=$ tidak pernah; 1 =jarang; $2=$ sering; $3=$ selalu. Kuesioner perilaku investasi anak memiliki Cronbach's alpha sebesar 0,848.

Kesejahteraan anak diukur dalam dua aspek, yaitu kesejahteraan objektif dan kesejahteraan subjektif. Kesejahteraan objektif adalah tingkat pemenuhan kebutuhan dasar dan perkembangan secara objektif, yaitu mengacu kepada standar normatif dan ideal (Sunarti, 2006). Kuesioner kesejahteraan objektif diacu dan dimodifikasi dari Sunarti (2001). Kuesioner kesejahteraan objektif berjumlah 20 pernyataan yang terbagi dalam lima dimensi yaitu pemenuhan pangan, sandang, papan, pendidikan dan kesehatan. Kuesioner kesejahteraan objektif anak menggunakan dua pilihan jawaban "ya" dan "tidak" dengan skor 1 (ya) dan 0 (tidak). Kuesioner kesejahteraan objektif memiliki Cronbach's alpha sebesar 0.502 .

Sementara itu, kesejahteraan subjektif anak adalah pandangan anak terhadap kesejahteraan dan kemiskinan yang dialaminya (Main, 2017). Kuesioner kesejahteraan subjektif remaja mengacu pada Sunarti (2006) yang dimodifikasi dan disesuaikan untuk kesejahteraan remaja. Kuesioner tersebut terdiri dari 21 pernyataan yang mengambarkan kesejahteraan yang dimiliki responden remaja. Remaja diminta menjawab setiap butir peryataan dengan pilihan jawaban tidak puas $=0$, cukup puas $=1$, puas $=2$ dan sangat puas $=3$. Kuesioner kesejahteraan subjektif memiliki Cronbach's alpha sebesar 0,916.

Data dari setiap variabel penelitian dijumlahkan dan ditransformasikan dalam bentuk indeks yaitu 1-100. Setelah itu, indeks dari setiap variabel penelitian dikategorikan. Pengategorian rendah, sedang dan tinggi berdasarkan cut off pengategorian oleh Sunarti, Tati, Atat, Noorhaisma dan Lembayung (2005) yaitu 00,0-60,0 dikategorikan rendah; 60,1-79,9 dikategorikan sedang; dan 80,1-100.0 dikategorikan tinggi. 
Analisis statistik deskriptif dilakukan dalam penelitian ini untuk mengidentifikasi karakteristik keluarga dan anak, nilai anak, perilaku investasi anak, dan kesejahteraan anak. Sementara itu, uji beda yang dilakukan dengan independent sample t-test bertujuan untuk menguji perbedaan karakteristik keluarga dan anak, nilai anak, perilaku investasi anak, dan kesejahteraan remaja berdasarkan jenis kelamin anak. Selanjunya, uji pengaruh menggunakan alat bantu SmartPLS untuk menganalisis pengaruh langsung dan tidak langsung karakteristik keluarga, karakteristik anak, nilai anak, dan perilaku investasi terhadap kesejahteraan anak.

\section{HASIL}

\section{Karakteristik Keluarga dan Anak}

Rata-rata usia ayah secara keseluruhan adalah 48 tahun, sedangkan ibu yaitu 43 tahun. Ratarata ayah dan ibu masuk dalam kategori usia dewasa madya (41-61 tahun). Besar keluarga dalam penelitian ini rata-rata berjumlah lima anggota keluarga. Lama pendidikan terendah ibu adalah nol tahun atau tidak sekolah dan tertinggi adalah 12 tahun atau setara dengan tamat sekolah menengah atas. Responden ayah memiliki capaian pendidikan terendah enam tahun atau setara dengan tamat sekolah dasar dan tertinggi adalah 12 tahun atau setara dengan tamat sekolah menengah atas. selanjutnya, hasil penelitian juga menemukan bahwa rata-rata pendapatan keluarga pada keluarga dari remaja laki-laki sebesar Rp724.545,00 sedangkan pada keluarga dari remaja perempuan sebesar Rp730.009,00 per bulan. Remaja pada penelitian ini berada dalam rentang umur 13-18 tahun dengan rata-rata usia responden anak yaitu 16 tahun.

\section{Nilai Anak}

Hasil penelitian menunjukkan bahwa secara keseluruhan nilai anak psikologi menempati rata-rata terbesar dengan nilai 77,11, sedangkan nilai anak ekonomi menpunyai nilai rata-rata terkecil dengan nilai 49,22.

Tabel 1 Rata-rata indeks nilai anak dan uji beda berdasarkan jenis kelamin

\begin{tabular}{lcrcc}
\hline \multicolumn{1}{c}{ Nilai anak } & $\begin{array}{c}\text { Laki- } \\
\text { laki }\end{array}$ & Perempuan & Total & $\begin{array}{c}p \text { - } \\
\text { value }\end{array}$ \\
\hline Nilai anak & 67,28 & 66,74 & 67,02 & 0,710 \\
total & 6,28 & 77,07 & 77,11 & 0,975 \\
Psikologi & 77,14 & 74,11 & 74,11 & 0,580 \\
Sosial & 75,27 & 49,01 & 49,22 & 0,849 \\
Ekonomi & 49,44 & & & \\
\hline
\end{tabular}

Nilai anak sosial ada diantara keduanya dengan indeks rata-rata 74,11. Dimensi nilai anak psikologi menpunyai nilai rata-rata tertinggi pada nilai anak. Artinya, orang tua menganggap memiliki anak baik laki-laki ataupun perempuan akan membawa keharmonisan dalam pernikahan dan anak akan membawa cinta/kasih dalam keluarga. Secara keseluruhan tidak ditemukan perbedaan nilai anak berdasarkan jenis kelamin anak. Anak perempuan dan anak laki-laki secara keseluruhan dipandang memberikan beban dan kebahagian yang sama.

Dimensi Psikologi. Dimensi psikologi memiliki rata-rata indeks tertinggi dalam dimensi nilai anak. Rata-rata indeks dimensi psikologi secara keseluruhan sebesar 77,11 . Pada dimensi ini lebih dari 50 persen orang tua menilai kehadiran anak akan menambah kebagaian, menambah suka cita, memberikan jaminan rasa aman di hari tua serta, membuat orang tua lebih semangat bekerja.

Dimensi Sosial. Rataan indeks dimensi sosial menempati urutan kedua setelah dimensi psikologi dengan nilai indeks 74,11 . Indeks tersebut menandakan bahwa orang tua sudah cukup memperhatikan lingkungan sosial dalam mempersepsikan nilai anak. Orang tua berpandangan bahwa anak yang terdidik akan menimbulkan penghargaan dan anak akan menjadi penerus keturunan, nama, dan tradisi keluarga.

Dimensi Ekonomi. Dimensi ekonomi memiliki nilai rataan indeks terendah diantara dimensi nilai anak lainnya. Rataan indeks nilai anak pada dimensi ekonomi sebesar 49,22 dengan indeks anak laki-laki sebesar 49,44 dan indeks nilai anak ekonomi perempuan sebesar 49,01. Artinya orang tua tidak berharap banyak terhadap bantuan ekonomi dari anak dikemudian hari sebagai penganti biaya membesarkan anak yang telah dikeluarkan.

\section{Perilaku Investasi Anak}

Rataan indeks perilaku investasi anak secara keseluruhan sebesar 44,10 (Tabel 2). Investasi nonmateri menempati rataan lebih besar dibandingkan dengan dimensi materi. Indeks rataan investasi nonmateri sebesar 48,73 sedangkan materi sebesar 39,99. Hasil tersebut menandakan orang tua lebih banyak melakukan investasi berupa nonmateri seperti menyiapkan sarapan untuk anak, menemani berdiskusi, mengajak anak bersosialisasi, dan berolahraga bersama. 
Tabel 2 Rata-rata indeks perilaku investasi anak dan uji beda berdasarkan jenis kelamin

\begin{tabular}{|c|c|c|c|c|}
\hline \multirow{2}{*}{$\begin{array}{c}\text { Investasi } \\
\text { anak }\end{array}$} & \multicolumn{3}{|c|}{ Rataan } & \multirow{2}{*}{$\begin{array}{c}p- \\
\text { value }\end{array}$} \\
\hline & $\begin{array}{c}\text { Laki- } \\
\text { laki }\end{array}$ & Perempuan & Total & \\
\hline $\begin{array}{l}\text { Perilaku } \\
\text { investasi } \\
\text { anak total }\end{array}$ & 44,91 & 43,80 & 44,36 & 0,653 \\
\hline Materi & 40,24 & 39,73 & 39,99 & 0,862 \\
\hline Nonmateri & 49,58 & 47,88 & 48,73 & 0,523 \\
\hline
\end{tabular}

Perilaku investasi materi dan nonmateri yang dilakukan oleh orang tua tidak memiliki perbedaan antara orang tua anak laki-laki dan orang tua anak perempuan. Hasil tersebut menandakan orang tua dalam melakukan investasi kepada anak tidak membedakan antara anak laki-laki dan anak perempuan.

Dimensi Materi. Orang tua anak laki-laki memiliki rata-rata indeks perilaku investasi pada dimensi materi sebesar 40,24 dan untuk anak perempuan 39,73 . Indeks tersebut masuk dalam kategori rendah. Perilaku investasi anak dimensi materi baik pada anak laki-laki maupun pada anak perempuan masih dalam kategori rendah. Artinya, orang tua masih sedikit dalam mengeluarkan uang atau dana untuk kebutuhan anak. Orang tua belum optimal menyediakan makan rutin sehari dua kali, menyediakan makanan dengan nutrisi yang baik, memberikan fasilitas anak untuk mengikuti kegiatan kursus keterampilan, serta mengikuti kegiatan keagamaan seperti mengaji.

Dimensi Nonmateri. Indeks perilaku investasi dimensi nonmateri pada orang tua anak laki-laki sebesar 49,58 dan indeks rataan anak perempuan sebesar 47,88 . Meskipun rataannya lebih tinggi daripada perilaku investasi dimensi materi namun hasil tersebut menandakan bahwa perilaku investasi nonmateri orang tua juga masih dalam kategori rendah. Hal ini disebabkan karena orang tua masih sedikit dalam meluangkan waktu untuk mengajak anak bercengkerama atau berdiskusi, menyiapkan sarapan pagi untuk anak, menanyakan tugastugas sekolah anak, serta orang tua kurang menyediakan waktu untuk berolahraga bersama

\section{Kesejahteraan Anak}

Kesejahteraan Objektif Anak. Hasil penelitian seperti yang tersaji pada Tabel 3 menunjukkan bahwa indeks rata-rata kesejahteraan objektif total termasuk dalam kategori sedang dengan nilai 70,35 . Indeks rata-rata tertinggi ada dalam dimensi kesejahteraan objekif pendidikan sebesar 85,15. Kesejahteraan objektif pendidikan meliputi keikutsertaan dalam pendidikan formal hingga pemenuhan kebutuhan sekolah seperti tas, buku, dan lain sebagainya. Dimensi dengan indeks rata-rata terendah adalah dimensi kesejahteraan papan dengan nilai indeks 55,88. Kesejahteraan papan meliputi kepemilikan kamar sendiri, lemari, serta meja belajar sendiri. Diantara keduanya terdapat dimensi pangan dengan indeks 71,42; dimensi sandang 79,20; dan dimensi kesehatan sebesar 60,08.

Hasil penelitian juga menemukan bahwa tidak adanya perbedaan kesejahteraan objektif antara anak laki-laki dan perempuan. Hal ini menandakan bahwa akses terhadap pemenuhan kebutuhan dasar antara anak lakilaki dan perempuan tidak berbeda. Anak lakilaki dan perempuan sama-sama memiliki akses terhadap pendidikan, kesehatan, pemenuhan makan, hingga tempat tinggal yang sama (Tabel 3).

Dimensi Pangan terkait dengan pemenuhan kebutuhan anak untuk makanan sehari-hari. Rataan indeks rata-rata laki-laki sebesar 75,00 dan rataan indeks perempuan sebesar 67,79. Indeks rata-rata tersebut menunjukan bahwa remaja masuk dalam kategori sedang pada dimensi pemenuhan makan.

Kesejahteraan pemenuhan dimensi pangan terpenuhi terbesar pada kemampuan pemenuhan kebutuhan makan utama tiga kali, sedangkan pemenuhan kebutuhan pangan dengan rataan indeks terendah terdapat pada kemampuan pemenuhan buah untuk dikonsumsi dua kali seminggu.

Tabel 3 Rata-rata indeks kesejahteraan objektif dan subjektif remaja dan uji beda berdasarkan jenis kelamin

\begin{tabular}{|c|c|c|c|c|}
\hline \multirow[b]{2}{*}{ Dimensi } & \multicolumn{3}{|c|}{ Rataan } & \multirow[b]{2}{*}{$\begin{array}{c}p- \\
\text { value }\end{array}$} \\
\hline & $\begin{array}{c}\text { Laki- } \\
\text { laki }\end{array}$ & Perempuan & Total & \\
\hline $\begin{array}{l}\text { Kesejahteraan } \\
\text { objektif total }\end{array}$ & 71,22 & 69,46 & 70,35 & 0,474 \\
\hline Pangan & 75,00 & 67,79 & 71,42 & 0,175 \\
\hline Sandang & 80,00 & 78,39 & 79,20 & 0,687 \\
\hline Papan & 53,33 & 58,47 & 55,88 & 0,346 \\
\hline Pendidikan & 85,55 & 87,47 & 85,15 & 0,832 \\
\hline Kesehatan & 62,22 & 57,90 & 60,08 & 0,213 \\
\hline $\begin{array}{l}\text { Kesejahteraan } \\
\text { subjektif total }\end{array}$ & 71,57 &, 60 & 58 & 88 \\
\hline $\begin{array}{l}\text { Fisik } \\
\text { ekonomi }\end{array}$ & 66,23 & 69,36 & 67,78 & 0,257 \\
\hline Psikologi & 73,33 & & 9 & 0,7 \\
\hline Sosial & 75,15 & 76.99 & 76.07 & 0,556 \\
\hline
\end{tabular}


Dimensi Sandang menjelaskan kondisi anak memperoleh kebutuhan dasar pakaian. Hasil penelitian menunjukkan bahwa remaja laki-laki $(80,00)$ memiliki rata-rata indeks pada pemenuhan sandang lebih tinggi dibandingkan perempuan $(78,39)$. Hal ini disebabkan karena laki-laki lebih banyak memiliki ragam pakaian dibandingkan perempuan.

Dimensi Papan terkait pada pemenuhan kebutuhan tempat tinggal anak beserta kebutuhan pendukungnya. Pendukung yang disebutkan dapat berupa tempat tinggal, meja belajar, atau lemari pakaian yang dibutuhkan anak. Pendukung-pendukung inilah yang kemudian menjadi pelengkap dalam pemenuhan tempat tinggal anak. Secara keseluruhan, indeks dimensi papan adalah sebesar 53,33 dan terkategori rendah. Hal ini disebabkan hanya setengah dari responden anak yang memiliki kamar, lemari, serta meja belajar sendiri.

Dimensi Pendidikan mencakup akses, fasilitas, dan kepemilikan kelengkapan dalam pendidikan menjadi tolak ukur dalam kesejahteraan objektif dimensi pendidikan. Kesejahteraan subjektif dimensi pendidikan pada anak laki-laki memiliki indeks rataan sebesar 87,47 dan perempuan 85,15 . Indeks tersebut menempatkan kesejahteraan pendidikan yang dimiliki anak masuk dalam kategori tinggi. Fakta ini didukung dengan temuan penelitian bahwa $80 \%$ responden anak pada penelitian ini mengikuti sekolah formal dan $90 \%$ memiliki alat tulis yang lengkap guna mendukung proses belajar.

Dimensi Kesehatan terkait dengan pemenuhan kebutuhan dasar anak untuk hidup sehat. Indeks rataan pada dimensi kesehatan adalah sebesar 62,22 dan angka tersebut menandakan kesejahteraan objektif anak pemenuhan kesehatan termasuk dalam kategori sedang. Hal tersebut dikarenakan lebih dari $50 \%$ responden ditanggung kesehatannya oleh pemerintah melalui asuransi BPJS yang diberikan secara cuma-cuma untuk masyaratak tidak mampu sehingga kontribusi keluarga terhadap pemenuhan kesejahteraan objektif dimensi kesehatan menjadi kecil.

Kesejahteraan Subjektif Anak pada penelitian ini terkait dengan kepuasan yang dirasakan anak terhadap kondisinya saat ini pada dimensi fisik ekonomi, sosial, serta psikologis. Tabel 3 menunjukan bahwa nilai indeks rata-rata kesejahteraan subjektif anak total termasuk kategori sedang yaitu 72,00. Dimensi kesejahteraan sosial memiliki indeks rataan terbesar yaitu 76,07. Kesejahteraan sosial mencakup tingkat kepuasan akan hubungan dengan orang tua, keluarga besar, hingga teman sebaya. Kesejahteraan subjektif dimensi fisik ekonomi menempati indeks total rata-rata terendah sebesar 67,78 (Tabel 3).

Hasil kajian mengungkapkan tidak ditemukan perbedaan antara anak laki-laki dan anak perempuan pada variabel kesejahteraan subjektif. Tidak terdapatnya perbedaan tersebut mencakup tiga dimensi secara garis besar, yaitu dimensi fisik ekonomi, psikologi serta dimensi sosial. Hal ini menandakan bahwa perasaan puas yang berkaitan dengan apa yang di miliki anak tidak berbeda antara anak laki-laki dan anak perempuan.

Dimensi Fisik Ekonomi yang terkait dengan kepuasan anak terhadap kondisi fisik dan ekonominya menunjukkan bahwa lebih dari setengah (50\%) responden anak merasa puas terhadap kemampuan orang tua untuk membiayai kesehatan serta pendidikan. Responden anak juga memiliki kepuasan terhadap pakaian yang dimiliki serta makanan yang dikonsumsi. Perasaan puas terhadap makanan dan pakaian berbanding terbalik dengan perasaan puas terhadap kepemilikan tabungan. Hanya (13\%) anak yang sangat puas terhadap keadaan tabungan yang dimiliki.

Dimensi Sosial terkait pada kepuasan anak terhadap hubungan anak dengan pihak-pihak lain. Hasil penelitian menunjukkan bahwa lebih dari $(80 \%)$ anak merasa puas dengan hubungan yang terjalin dengan orang tuanya. Responden anak juga merasa puas terhadap hubungan dirinya dengan keluarga besar dan teman sebaya.

Dimensi Psikologi yang ditemukan dalam penelitian ini salah satunya adalah dukungan serta perhatian orang tua terhadap pendidikan telah dirasakan oleh hampir keseluruhan anak. Hasil penelitian menunjukkan bahwa tiga dari lima anak (63\%) merasa cukup puas dengan perannya sebagai anak di keluarga dan 53 persen anak merasa puas dengan perannya sebagai murid di sekolah.

\section{Pengaruh Karakteristik Keluarga, Karakteristik Anak, Nilai Anak, dan Perilaku Investasi Anak terhadap Kesejahteraan Anak}

Hasil model uji pengaruh karakteristik keluarga, karakteristik anak, nilai anak, dan perilaku investasi anak terhadap kesejahteraan anak menunjukkan angka $R$-square sebesar 17,2 
persen (Gambar 1) yang berarti model menjekaskan 17,2 persen variabel yang memengaruhi kesejahteraan anak dan sisanya sebesar 82,8 persen dipengaruhi variabel di luar penelitian. Kesejahteraan anak hanya dipengaruhi secara langsung oleh satu variabel yaitu perilaku investasi anak. Karakteristik anak, karakteristik keluarga, dan nilai anak tidak memiliki pengaruh langsung kepada kesejahteraan anak.

Pengaruh langsung kepada kesejahteraan anak ditemukan pada variabel beas perilaku investasi anak. Perilaku investasi anak berpengaruh positif signifikan terhadap kesejahteraan anak dengan nilai outer loading $0,384, t>1,96$. Hal ini bermakna peningkatan perilaku investasi anak yang diberikan orang tua akan semakin meningkatkan kesejahteraan yang dimiliki remaja.

Sementara itu, nilai anak berpengaruh langsung secara positif signifikan terhadap perilaku investasi anak dengan nilai outer loading 0,306, t>1,96. Hal ini bermakna peningkatan nilai anak yang dipersepsikan orang tua bahwa kehadiran anak lebih banyak memberikan manfaat dibandingkan bebas akan meningkatkan perilaku investasi yang dilakukan oleh orang tua. Indikator yang paling banyak berkontribusi pada variabel nilai anak adalah nilai anak psikologi sebesar 0,843 , kemudian nilai anak sosial sebesar 0,832. Kontribusi terkecil terdapat pada nilai anak ekonomi sebesar 0,445 (Gambar 1).

Tabel 4 Koefiensi pengaruh karakteristik keluarga, karakteristik anak, nilai anak, dan perilaku investasi anak terhadap kesejahteraan remaja

\begin{tabular}{|c|c|c|c|c|c|c|}
\hline \multirow{3}{*}{ Variabel } & \multirow{3}{*}{ DE } & \multirow{2}{*}{\multicolumn{4}{|c|}{ Kesejahteraan Anak }} & \multirow{3}{*}{ TE } \\
\hline & & & & & & \\
\hline & & $\begin{array}{l}\mathrm{K} \\
\mathrm{K}\end{array}$ & $\mathrm{KA}$ & NA & IA & \\
\hline $\begin{array}{l}\text { Karakteri } \\
\text { stik } \\
\text { keluarga }\end{array}$ & $\begin{array}{r}0,15 \\
0\end{array}$ & - & $\begin{array}{r}0,03 \\
9\end{array}$ & $\begin{array}{r}0,02 \\
5\end{array}$ & $\begin{array}{r}0,00 \\
9\end{array}$ & $\begin{array}{r}0,12 \\
7\end{array}$ \\
\hline $\begin{array}{l}\text { Karakteri } \\
\text { stik anak }\end{array}$ & $\begin{array}{r}0,16 \\
0\end{array}$ & - & - & $\begin{array}{r}0,00 \\
1\end{array}$ & $\begin{array}{r}0,02 \\
1\end{array}$ & 0,18 \\
\hline $\begin{array}{l}\text { Nilai } \\
\text { Anak }\end{array}$ & $\begin{array}{r}0,09 \\
9\end{array}$ & - & - & - & $\begin{array}{r}0,11 \\
8^{*}\end{array}$ & $\begin{array}{r}0,08 \\
9^{*}\end{array}$ \\
\hline $\begin{array}{l}\text { Perilaku } \\
\text { investasi }\end{array}$ & $\begin{array}{r}0,38 \\
4^{*}\end{array}$ & - & - & - & - & $\begin{array}{r}0,38 \\
4^{*}\end{array}$ \\
\hline
\end{tabular}

Keterangan: signifikan pada $\mathrm{t}>1.96 ; \mathrm{KK}=$ Karakteristik keluarga; $K A=$ Karakteristik anak; $N A=$ Nilai Anak; $I A=$ Investasi Anak; DE = Direct effect IE = Indirect effect; $T E=$ Total effect
Hasil kajian memperlihatkan bahwa terdapat pengaruh tidak langsung antara nilai anak terhadap kesejahteraan anak melalui perilaku investasi anak (Tabel 4). Pengaruh tidak langsung tersebut memiliki $t$-statistics 2,218 dengan $p$-values 0,027. Hal tersebut menunjukan bahwa dalam mewujudkan kesejahteraan anak tidak cukup hanya dengan memiliki persepsi nilai anak yang baik. Kesejahteraan anak dapat diwujudkan dengan memiliki nilai anak yang baik yang kemudian membentuk perilaku investasi anak yang tinggi juga. Perilaku investasi anak lah yang kemudian berpengaruh secara langsung terhadap kesejahteraan remaja.

Hasil penelitian juga menunjukkan bahwa perilaku investasi anak nonmateri yaitu waktu mempunyai kontribusi paling besar pada variabel laten perilaku investasi anak. Hal ini menandakan bahwa ibu lebih banyak memberikan investasi nonmateri dibandingkan dengan investasi materi. Variabel laten kesejahteraan anak memiliki dua kontribusi yaitu kesejahteraan objektif dan subjektif. Pada penelitian ini kesejahteraan subjektif memiliki kontribusi lebih besar dibandingkan kesejahteraan objektif (Gambar 1).

\section{PEMBAHASAN}

Undang-Undang No 4 Tahun 1979 menyatakan bahwa kesejahteraan anak adalah suatu tata kehidupan dan penghidupan anak yang dapat menjamin pertumbuhan dan perkembangannya dengan wajar, secara rohani, jasmani, dan sosial. Kesejahteraan anak merupakan suatu proses interaksi yang dinamis antara faktor dari luar diri anak (latar belakang sosial ekonomi, keluarga, dan keadaan lingkungan) dengan karakteristiknya (kepribadian, kemampuan kognitif, dan sebagainya) untuk memuaskan kebutuhannya dan meningkatkan sumberdaya (Yoo \& Ahn, 2017). KPPPA (2016) memandang satu perspektif bahwa kesejahteraan anak adalah kewajiban atau tanggung jawab keluarga.

Anak sebagai bagian dari keluarga menjadikan institusi terkecil dalam masyarakat tersebut memiliki tanggung jawab terhadap kesejahteraan anak. Salah satu yang dapat dilakukan orang tua adalah dengan memberikan perilaku investasi pada anak secara baik (Lampropoulou, 2018). Perilaku investasi anak adalah salah satu faktor kunci dalam pencapaian kesejahteraan masa depan anak (Hedges, Mulder, James, \& Lawson, 2016). 


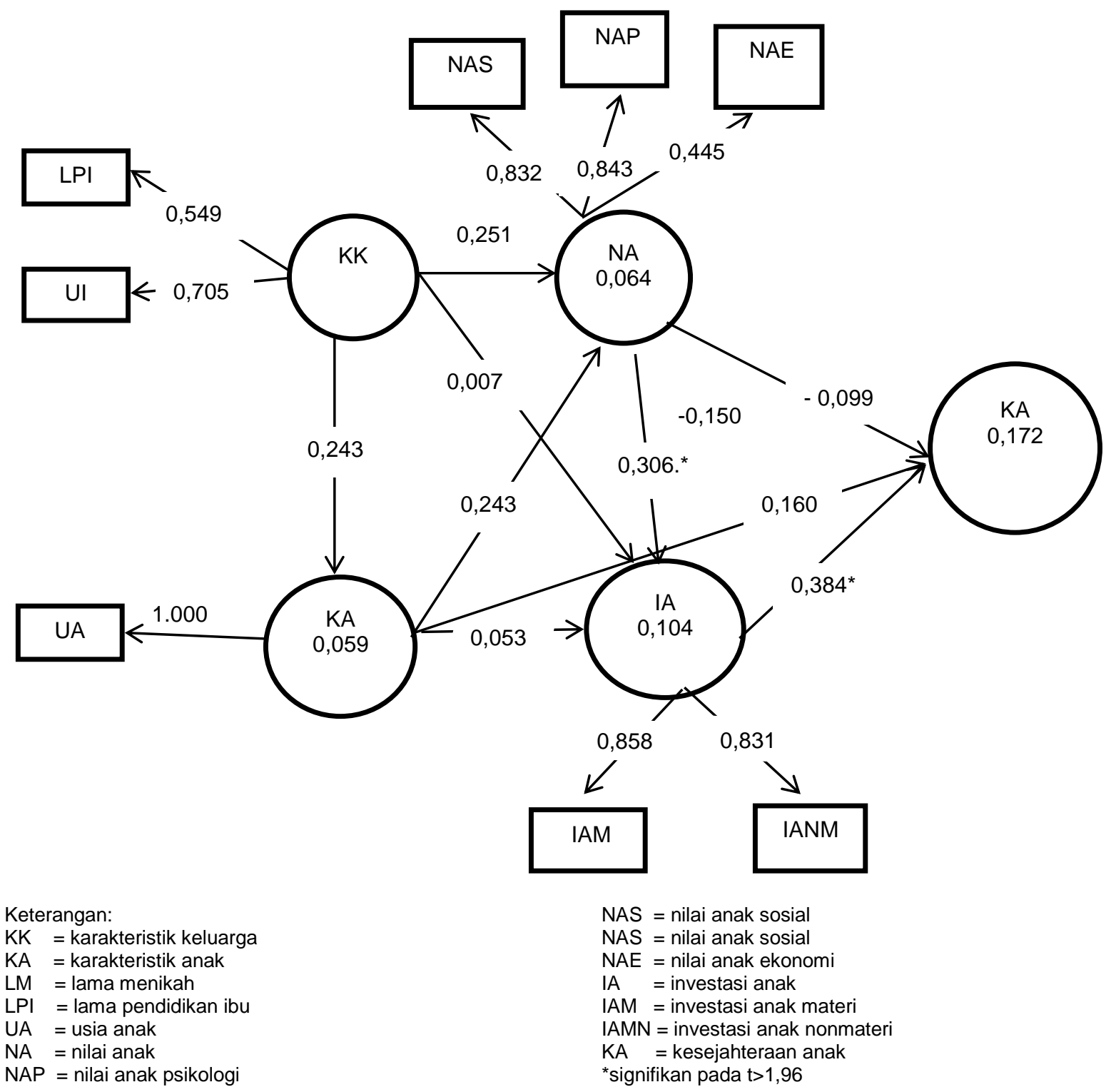

Gambar 1 Model pengaruh karakteristik keluarga, karakteristik anak, nilai anak, perilaku investasi anak terhadap kesejahteraan anak

Perilaku investasi anak terbagi menjadi dua, yaitu materi dan nonmateri. Pada penelitian ini, orang tua lebih banyak melakukan investasi pada nonmateri dibandingkan materi. Beberapa perilaku yang ditemukan adalah menghabiskan waktu bersama anak seperti mengajak diskusi anak, menanyakan tugas sekolah anak, berolahraga bersama, dan menyiapkan sarapan pagi merupakan perilaku investasi yang lebih sering dilakukan orang tua dalam penelitian ini. Penelitian ini menguatkan penelitian terdahulu Ross (2019) yang mengatakan investasi waktu oleh orang tua akan memengaruhi kualitas sumber daya dan kesejahteraan remaja.

Penelitian ini dilakukan pada keluarga yang tinggal di rusunawa yang hampir smeuanya adalah korban penggusuran. Peningkatan pengeluaran keluarga pascapenggusuran membuat keluarga mengalami kesulitan ekonomi (Syafruddin \& Adi, 2017). Orang tua mengalami kesulitan untuk menyisihkan pendapatan untuk biaya kegiatan sekolah serta kegiatan lain seperti rekreasi keluarga.

Hasil penelitian ini menguatkan penelitian terdahulu yang mengatakan bahwa tingkat kekayaaan dan kemiskinan memengaruhi pola perilaku investasi orang tua pada anak (Coddington, Mistry, Baliley, 2014; Rahmiwati \& Pupsitasari, 2013; Rosidah, Hartoyo, \& Muflikhati, 2012). Selain keadaan ekonomi, faktor lain yang memengaruhi perilaku investasi adalah nilai anak orang tua terhadap anak. Perilaku Investasi yang dilakukan oleh keluarga 
tidak lepas dari pengaruh bagaimana nilai yang dianut orang tua terkait dengan nilai seorang anak. Pada penelitian ini ditemukan nilai anak paling besar kontribusinya adalah nilai anak psikologi. Orang tua berpandangan bahwa kehadiran anak akan membawa suka cita, kebahagiaan, dan kasih sayang di tengahtengah keluarga. Nilai tersebut yang kemudian akan memengaruhi keinginan orang tua memiliki dan membesarkan anak (Oktriyanto, Puspitawati, \& Muflikhati, 2015) serta memengaruhi pola serta perilaku investasi orang tua terhadap anak (Albert, Trommsdorff, Mayer, \& Schwarz, 2005).

Berbeda dalam penelitian sebelumnya, yaitu pada penelitian Mulatsih, Mulyaningrum, dan Pambudi (2002) dan Hendra (2018) yang mengatakan bahwa perbedaan pandangan terhadap nilai anak laki-laki dan anak perempuan turut memengaruhi bagaimana sebuah keluarga berinvestasi. Penelitian ini tidak menemukan perbedaan signifikan antara perilaku investasi ibu terhadap anak laki-laki dan perempuan yang sudah memasuki usia remaja. Penelitian menemukan bahwa responden baik ibu dari anak laki-laki dan ibu dari anak perempuan dalam penelitian ini sama-sama memiliki perilaku investasi yang rendah. Selain itu, penelitian ini juga tidak menemukan adanya perbedaan yang signifikan pada kesejahteraan anak baik anak laki-laki dan perempuan. Hal tersebut mengindikasikan bahwa keluarga di rusunawa walaupun mengalami kesulitan ekonomi namun belum sampai terdesak untuk memilih antara anak laki-laki dan perempuan dalam berinvestasi (Chen, 2017; Pufall et al., 2016).

Hasil analisis uji pengaruh ditemukan bahwa perilaku investasi anak berpengaruh langsung secara positif signifikan terhadap kesejahteraan anak. Temuan tersebut menegaskan bahwa semakin besar perilaku investasi yang dimiliki orang tua maka semakin tinggi pula kesejahteraan anak tersebut. Sebaliknya, semakin rendah perilaku investasi akan semakin rendah pula kesejahteraan anak. Hasil penelitian tersebut sesuai dengan penelitian yang menyebutkan bahwa mempersiapkan anak mencapai kesejahteraan dapat dilakukan dengan melakukan investasi pada anak (Antfolk \& Sjölund, 2018; Ross, 2019). Karakteristik orang tua dan karakteristik anak pada penelitian ini tidak memilki pengaruh terhadap kesejahteraan anak. Hal ini berbeda dengan penelitian (Abubakar et al., 2013; Bastaits, Pasteels, \& Mortelmans 2018; Cederbaum et al., 2017) yang mengatakan bahwa karakteristik keluarga memengaruhi

kesejahteraan anak terbentuk.

bagaimana

Pengaruh tidak langsung ditemukan pada nilai anak terhadap kesejahteraan anak. Nilai anak berpengaruh pada kesejahteraan anak melalui perilaku investasi anak. Artinya, dapat dimaknai bahwa saat orang tua menganggap penting nilai anak maka orang tua tersebut akan melakukan perilaku investasi sehingga akan memberikan kesejahteraan pada anak tersebut. Hasil penelitian ini juga menguatkan studi yang dilakukan sebelumnya oleh Abufhele, Behrman dan Bravo (2017), Bahri dan Hartoyo (2013), serta Beaulieu dan Bugental (2008) yang menyebutkan bahwa nilai anak akan berpengaruh terhadap perilaku investasi dan investasi anak merupakan salah satu faktorfaktor yang memengaruhi kesejahteraan anak (Utter et al., 2017).

\section{SIMPULAN DAN SARAN}

Orang tua dari remaja pada penelitian ini masuk dalam kategori dewasa madya yaitu dalam rentang umur ayah 41 tahun hingga 61 tahun. Rata-rata usia ibu 43 tahun dan usia ayah 48 tahun. Orang tua memiliki nilai anak dalam kategori sedang dengan dominasi dimensi psikologi lebih tinggi dibandingkan sosial dan ekonomi. Pengharapan terhadap jaminan rasa aman di hari tua menjadi motivasi orang tua dalam memiliki dan membesarkan anak. Perilaku investasi baik dalam dimensi materi maupun nonmateri masuk dalam kategori rendah. Orang tua belum memiliki perilaku investasi yang cukup untuk anak-anak mereka. Hasil penelitian menemukan tidak adanya perbedaan dalam hal nilai anak, perilaku investasi anak, dan juga kesejahteraan anak antara remaja laki-laki dan perempuan dalam penelitian ini. Hasil penelitian menegaskan adanya pengaruh langsung signifikan perilaku investasi anak terhadap kesejahteraan anak. Pengaruh tidak langsung ditemukan pada nilai anak terhadap kesejahteraan anak melalui perilaku investasi. Temuan tersbeut menunjukkan bahwa semakin tinggi nilai anak yang diberikan orang tua akan semakin tinggi perilaku investasi yang dilakukan untuk anak. Perilaku investasi anak menjadi faktor yang berpengaruh terhadap kesejahteraan anak, yang bermakna bahwa semakin tinggi orang tua melakukan investasi terhadap anak, akan menaikkan kesejahteraan anak.

Berdasarkan penelitian, orang tua masih terkategori rendah dalam berinvestasi maka orang tua perlu meningkatkan investasi pada 
anak. Investasi bidang pendidikan nonformal harus ditingkatkan. Orang tua dapat meningkatkan dengan memberikan pembelajaran keterampilan hidup pada anak. Orang tua juga dapat meningkatkan perilaku investasi dengan cara memiliki nilai anak yang lebih baik lagi; yaitu dengan menanamkan kesadaran pada diri sendiri betapa banyak manfaat yang diperoleh orang tua atas kehadiran anak di dalam keluarga Selain itu, lembaga masyarakat diharapkan mampu membantu dengan mengadakan kegiatankegiatan pemberdayaan remaja dalam bidang ketrampilan nonformal. Saran untuk pemerintah diharapkan mampu untuk meningkatkan program-program pendidikan yang mampu mencetak lulusan-lulusan siap kerja seperti lebih banyak membangun sekolah menengah kejuruan. Program tersebut dapat membantu keluarga dalam melakukan investasi dan pemenuhan kesejahteraan anak. Untuk peneliti selanjutnya, penelitian ini dapat dilengkapi dengan perluasan wilayah penelitian, melihat perbedaan nilai, perilaku investasi, dan kesejahteraan anak berdasarkan perbedaan dan komparasi persepsi ayah dan ibu.

\section{DAFTAR PUSTAKA}

[BPS] Badan Pusat Statistik. (2019). Penduduk Berumur 15 Keatas Menurut Golongan Umur dan Jenis Kegiatan. Jakarta, ID: Badan Pusat Statistik.

[KEMENDIKBUD] Kementerian Pendidikan dan Kebudayaan. (2017). Ikhtisar Data Pendidikan 2016/2017. Jakarta, ID: KEMENDIKBUD.

[KEMNAKER] Kementerian Ketenagakerjaan Indonesia. (2014). Peta Jalan (roadmap) Menuju Indonesia Bebas Pekerja Anak 2022. Jakarta, ID: KEMNAKER.

[KPPPA] Kementerian Pemberdayaan Perempuan dan Perlindungan Anak. (2016). Booklet Indeks Komplosit Komposit Kesejahteraan Anak. Jakarta, ID: KPPA.

Abubakar, A., Alonso-Arbiol, I., Van de Vijver, F. J., Murugami, M., Mazrui, L., \& Arasa, J. (2013). Attachment and psychological wellbeing among adolescents with and without disabilities in Kenya: The mediating role of identity formation. Journal of adolescence, 36(5), 849-857. doi:10.1016/ j.adolescence.2013.05.006.

Abufhele, A., Behrman, J., \& Bravo, D. (2017). Parental preferences and allocations of investments in children's learning and health within families. Social Science \& Medicine, 194(9), 76-86. doi:10.1016/j. socscimed.2017.09.051.

Albert, I., Trommsdorff, G., Mayer, B., \& Schwarz, B. (2005). Value of children in urban and rural Indonesia: Sociodemographic indicators, cultural aspects, and empirical findings. Konstanzer Online Publikations System, (2005), 171-207.

Antfolk, J., \& Sjölund, A. (2018). High parental investment in childhood is associated with increased mate value in adulthood. Personality and Individual Differences, 127(2), 144-150. doi:10.1016/j.paid.2018.02.004.

Bahri, N. M., \& Hartoyo, H. (2013). Perilaku investasi anak pada keluarga miskin dan tidak miskin. Jurnal IImu Keluarga \& Konsumen, 6(3), 190-198. doi:10.24156/ jikk.2013.6.3.190.

Bastaits, K., Pasteels, I., \& Mortelmans, D. (2018). How do post-divorce paternal and maternal family trajectories relate to adolescents' subjective wellbeing?. Journal of adolescence, 64, 98$108 . \quad$ doi:10.1016/j.adolescence 2018.02.005

Beaulieu, D. A., \& Bugental, D. (2008). Contingent parental investment: An evolutionary framework for understanding early interaction between mothers and children. Evolution and Human Behavior, 29(4), 249-255. doi:10.1016/j. evolhumbehav.2008.01.002.

Cardia, E., \& Gomme, P. (2018). Market work, housework and childcare: A time use approach. Review of Economic Dynamics, 29(1), 1-14. doi:10.1016/j.red. 2017.12.002.

Cederbaum, J. A., He, A. S., Fulginiti, A., Sullivan, K., Krauss, M. D., Amutah, N., \& Pohle, C. (2017). Caregiver qualities, family closeness, and the well-being of adolescents engaged in the child welfare systdcem. Children and Youth Services Review, 73(7), 113-120. doi:10.1016/j. childyouth.2016.12.007.

Chen, Q. (2017). Relaxed population policy, family size and parental investments in children's education in rural Northwestern China. International Journal of Educational Development, 54(9), 39-50. doi:10.1016/j. ijedudev.2017.03.009.

Coddington, C. H., Mistry, R. S., \& Bailey, A. L. (2014). Socioeconomic status and 
receptive vocabulary development: Replication of the parental investment model with Chilean preschoolers and their families. Early Childhood Research Quarterly, 29(4), 538-549. doi:10.1016/j. ecresq.2014.06.004.

Folbre, N. (2008). Valuing children: Rethinking the economics of the family. United States, US: Harvard University Press.

Hartoyo, Latifah, M., \& Mulyani, S. R. (2011). Studi nilai anak, jumlah anak yang diinginkan, dan keikutsertaan orang tua dalam program KB. Jurnal IImu Keluarga dan Konsumen, 4(1), 37-45. doi:10.24156 /jikk.2011.4.1.37.

Hartoyo. (1988). Investing in children: Study of rural families in Indonesia (Disertasi). Blacksburg, US: Virginia Polytechnic Institute.

Hedges, S., Mulder, M. B., James, S., \& Lawson, D. W. (2016). Sending children to school: rural livelihoods and parental investment in education in northern Tanzania. Evolution and human behavior, 37(2), 142-151. doi:10.1016/j. evolhumbehav.2015.10.001.

Hendra, J. R. (2018). Kajian perspektif gender pada pola asuh orang tua bagi perkembangan anak di Desa Batu Merah Kota Ambon. FIKRATUNA: Jurnal Penelitian Sosial Keagamaan, 7(2),1-18.

Januardi, A. F., Achmadi, J.C., \& Fortuna, C.I. (2017). Seperti puing: laporan penggusuran paksa di wilayah DKI Jakarta tahun 2016. Jakarta(ID): Lembaga Bantuan Hukum.

Jiang, Y., Zhang, J., Ming, H., Huang, S., \& Lin, D. (2019). Stressful life events and wellbeing among rural-to-urban migrant adolescents: The moderating role of the stress mindset and differences between genders. Journal of adolescence, 74(5), 24-32. doi:10.1016/j.adolescence .2019 .05 .005

Lampropoulou, A. (2018). Personality, school, and family: What is their role in adolescents' subjective well-being. Journal of adolescence, 67(5), 12-21. doi:10.1016/ j.adolescence.2018.05.013.

Larasati, D. A., \& Hartoyo, H. (2016). The influence of cultural values and value of children on mother's time allocation at Cimanuk watershed families. Journal of Family Sciences, 1(2), 13-24. doi:10.29244/jfs.1.2.13-24.
Main, G. (2017). Child poverty and subjective well-being: The impact of children's perceptions of fairness and involvement in intra-household sharing. Children and Youth Services Review. doi:10.1016/j. childyouth.2017.06.031.

Mulatsih, S, Mulyaningrum, \& Pambudi, R. (2002). Perilaku investasi pendidikan bagi anak perempuan dibandingkan anak lakilaki: Suatu tinjauan ekonomis. Bogor, ID: Fakultas Peternakan, Institut Pertanian Bogor.

Oktriyanto, O., Puspitawati, H., \& Muflikhati, I. (2015). Nilai anak dan jumlah anak yang diinginkan pasangan usia subur di wilayah perdesaan dan perkotaan. Jurnal IImu Keluarga \& Konsumen, 8(1), 1-9. doi:https://doi.org/10.24156/jikk.2015.8.1.1

Pufall, E., Eaton, J. W., Nyamukapa, C., Schur, N., Takaruza, A., \& Gregson, S. (2016). The relationship between parental education and children's schooling in a time of economic turmoil: The case of east Zimbabwe, 2001 to 2011. International journal of educational development, 51(9), 125-134. doi:10.1016/j.ijedudev.2016 .09 .003 .

Rahmiati, T. S. A., \& Puspitawati, H. (2013). Hubungan antara investasi dan kualitas anak usia sekolah pada keluarga petani. Jurnal IImu Keluarga \& Konsumen, 6(3), 154-162. doi:10.24156/ jikk.2013.6.3.154.

Rosidah, U., Hartoyo, H., \& Muflikhati, I. (2012). Kajian strategi koping dan perilaku investasi anak pada keluarga buruh pemetik melati gambir. Jurnal IImu Keluarga \& Konsumen, 5(1), 77-87. doi:10.24156/jikk.2012.5.1.77.

Ross, P. H. (2019). Occupation aspirations, education investment, and cognitive outcomes: evidence from Indian adolescents. World Development, 123, 104-613. doi:10.1016/j.worlddev .2019 .104613 .

Sam, D. L. (2001). Value of children: Effects of globalization on fertility behavior and childrearing practices in Ghana. Institute of African Studies Research Review, 17(2), 5-16. doi:10.1111/j.14640597.2001.00215.x.

Sohr-Preston, S. L., Scaramella, L. V., Martin, M. J., Neppl, T. K., Ontai, L., \& Conger, R. (2013). Parental socioeconomic status, communication, and children's vocabulary 
development: A third-generation test of the family investment model. Child development, 84(3), 1046-1062. doi:10. $1111 /$ cdev. 12023.

Sunarti, E. (2001). Studi ketahanan keluarga dan ukurannya: telaah kasus pengaruhnya terhadap kualitas kehamilan (Disertasi). Bogor, ID: Institut Pertanian Bogor.

Sunarti, E. (2006). Indikator keluarga sejahtera: Sejarah pengembangan, evaluasi, dan keberlanjutannya (Naskah Akademik BKKBN). Bogor, ID: Institut Pertanian Bogor.

Sunarti, E., Tati, Atat, S. N., Noorhaisma, R., \& Lembayung. (2005). Pengaruh tekanan ekonomi keluarga, dukungan sosial, kualitas pernikahan, pengasuhan, dan kecerdasan emosi anak terhadap prestasi belajar anak. Media Gizi dan Keluarga, 29(1), 34-40.

Surachman, A., \& Hartoyo. (2015). Parental investment and poverty dynamics in West Java, Indonesia. Journal of Family and Economic Issues, 36(3), 340-352.
Syafruddin, P., \& Adi, I. R. (2017). Relokasi berdampak terhadap kesejahteraan dari sisi kondisi ekonomi warga Kampung Pulo. Jurnal IImu Kesejahteraan Sosial, 18(2). doi:10.7454/jurnalkessos.v18i2.103.

Utter, J., Denny, S., Peiris-John, R., Moselen, E., Dyson, B., \& Clark, T. (2017). Family meals and adolescent emotional wellbeing: Findings from a national study. Journal of nutrition education and behavior, 49(1), 67-72. doi:10.1016 /j.jneb.2016.09.002.

Vasilyeva, M., Dearing, E., Ivanova, A., Shen, C., \& Kardanova, E. (2018). Testing the family investment model in Russia: Estimating indirect effects of SES and parental beliefs on the literacy skills of firstgraders. Early Childhood Research Quarterly, 42(3), 11-20. doi:10.1016 /j.ecresq.2017.08.003.

Yoo, J. P., \& Ahn, J. (2017). Understanding the typologies of child subjective well-being: A cross-country comparison. Children and Youth ServicesReview, 80(3) , 22-30. doi:10.1016/j.ecresq.2017.08.003. 